\title{
Genesis and Nature of Moral and Legal Norms. Leon Petrażycki's Naturalistic Solution
}

\author{
Andrzej Dąbrowski \\ University of Information Technology \\ and Management in Rzeszow, \\ Poland \\ e-mail: $\underline{\text { adabrowski@wsiz.rzeszow.pl }}$
}

\begin{abstract}
:
The aim of the paper is to examine the nature of moral and legal norms in a broader context: first, taking into account logical and methodological assumptions, second, in the perspective of psychology of emotions and legal policy. The basic subject of the research carried out by Leon Petrażycki was represented by law. Originally, it had a psychological character, not an objective, eternal, and unchanging one. To fully understand the genesis and nature of morality and law, Petrażycki addressed the study of mental phenomena, especially emotional experiences. First, however, he developed appropriate rules of logic and scientific methodology. Then he developed a new classification of mental phenomena, among which the fundamental role is played by bilateral (passive-active) emotions. At some stage, emotions begin to cooperate with cognitive processes, first of all with imaginations. Imaginations of acts, such as theft, betrayal, murder, can cause repulsive emotions, and type imaginations, such as truthfulness, charity, justice can evoke apulsive emotions. On the basis of such associations, judgments are created over time, the content of which becomes a basis for fundamental rules of conduct, that is, for norms. There are two fundamentally different types of norms: moral norms and legal norms. The norms of the first type are imperative and represent the nature of validity (they are obeyed), while the norms of the second type are imperative-attributive and they also always entitle someone to something, i.e. they give someone a right. This division determines a fundamental difference between morality and law.

Keywords: law, classification of mental phenomena, emotions, moral norms, legal norms.
\end{abstract}

\section{Introduction to Petrażycki's Theory of Law and His Politics of Law}

Emotions are an integral part of human beings. They are very important in everyday life: at work, at school, at home, in art, in research, and in every action and conversation. They provide us with effective operation and success. Emotions often are helpful. Often, but not always. Today we know 
a lot about emotions, however, we still have much to discover. For example, we do not know exactly what emotions are.

According to Leon Petrażycki the phenomenon of law is not entirely objective, immutable and independent from the subject. Primarily the law exists in the subject's mind as an experience that is being projected outside. Legal norms that are contained in constitutions and codes are merely projections of these primary legal experiences. Petrażycki aimed his conception mainly against natural law theories, but partly also against positivistic approaches [cf. 44, see also 1, 2, 19, 21, 37, $60,61,63]$. Legal experiences belong to basic mental facts. They are 'ethical experiences, and emotions connected with them possess attributive character' that is two-sided (binding and demanding). Actually their character is imperative-attributive and it is contrary to the character of positive emotion experiences (moral phenomena belong here), the latter bind one-sidedly [44, vol. 1, p. 153]. ${ }^{1}$

Petrażycki's theory concerns the basic concept of law but is not limited to it. Within broadly understood generic law he distinguished four basic kinds: intuitive law, positive law, official law, and unofficial law. The positive law contains projections of normative facts that are constituted by an external authority figure (God, monarch, lawmaker). Intuitive law (or natural law) does not contain such projections. It arises in independence from authorities, is individually variable, depends on unique biography of a man, on his character, personal experience and education [44, vol. 2, pp. 249-251]. Official law is applied and supported by state authority, whereas unofficial law has not such a backing - it is not applied nor supported by the state. It is present in various social groups (in family, in organized groups, e.g. in organized crime) [44, vol. 2, pp. 306-307]. The law of all kinds functions by 1. Arousing or inhibiting some motives of action (or of abandoning them), 2. Developing and preserving some tendencies and weakening and eliminating others [43, p. 14].

Petrażycki was convinced that relations between people might be different than they are, and the world would be better. The way to the better leads - according to him - mainly by the law, for it has got a big influence upon how human communities and states operate, and that is by its motivational and educational function. Nevertheless what is necessary is a deep reform in science and law and - as a consequence - a change in human consciousness. As the tool for it he meant scientific politics of the law: 'The highest good that we are obliged to seek in the realm of politics in general and in politics of law in detail is the moral development of man, the domination of high rational ethics over humanity, i.e. the ideal of love' [53, p. 25]. Support for the moral development of societies and whole the humanity - according to Petrażycki - should be based on '1. Rational directing human activity - individual and collective as well - by an appropriate motivation of the law, 2. Perfecting human psyche, purifying it from bad antisocial tendencies and introducing and strengthening the contrary inclinations' [43, p. 14], [cf. 45, 53, see also 28, 35, 57, 69].

The question if the moral progress is possible always was controversial and until today nothing has changed. One could argue that a human is born as a primitive being, with its primary reflexes and instincts (to obtain food, to fight, to defend oneself, to seek for a sexual partner). Since the beginning a human being possesses a set of inborn cognitive abilities and communicational, social and moral predispositions, but the degree to which they would develop depends on the education and the environment in which he lives. Left alone in difficult conditions of the world he would not become a civilized person. It is possible that every new generation is born as primitive and needs to be educated and civilized. The moral progress is difficult because of the freedom of man itself, his tendency to evil and the presence of evil. Morals assume the freedom of choice between various options - the choice between good and bad. Making choices is a persistent disposition of a human being, and one cannot avoid it. A man does the moral evil and - on the basis of freedom of choice - he would always do. The state of affairs makes any moral progress very difficult or impossible at all.

Petrażycki has no doubts that moral and social progress of humanity is possible [53, p. 25 , see also 35, 45, 57, 69]. In order to believe it, that is enough that one reads Corpus iuris and Gaius. History of law describes gradual changes in ethical life of man and presents how the progress is being done. Petrażycki gives a few examples. One of them is history of bond right. Evolution of 
Roman, German or Russian law reveals that originally ethical virtues which supported the institution of obligation, that is, they made for obligation fulfillment, were very little developed, and because of that the justice had to apply very firm and tight means of coercion. According to the mental evolution and to the development of more and more noble ethical motives sanctions became more and more subtle and delicate. Another Petrażycki's example are relations between members of a family, married couples and between parents and their children. Originally they were very severe and based on absolute subordination and rigor. Various means of suppression and taming were applied. Nevertheless over time they become more civilized. The position of woman improved and the attitude to children changed [53, pp. 25-28].

According to Petrażycki, in the process of moral perfecting the main role should be performed by the law. He believes that that rational politics is an important factor of moral progress [53, p. 29]. That is because the law has the ability to weaken and eliminate some given inclinations and behaviors and to strengthen and develop the others. He argues by giving the example of Roman law concerning possessio and the criminal law. The history points out that not only regulations contained in the law concerning possession removed motives for deeds that were harmful for the economy and social coexistence, but also they structured positive patterns of behavior, taught how to act in harmony and how to respect property and its owners. One can see the educational aspect in that how the criminal law works. Its aim is not to fight against the crime but to educate a worthy man. It is so, because the concern about the punishment keeps people from perpetrating crimes and shapes their character positively [53, pp. 29-44].

Petrażycki claims that the humanity should be led by 'the great ideal of panhuman love.' The principle that love is an ideal and the highest good is in his view an axiom of practical reason and as such it does not need to nor might be proved [53, p. 25]. It is so for any proof of it would have to undermine the thesis being concerned: values upon which one would argue - satisfaction, wealth, happiness - would have to be put in the place of the ideal, and then the primary principle would lose the status of an axiom. Generally Petrażycki's ideal of love means rejecting egoism of many kinds: social, national and state one. Its aim is to remove differentiation of people by nationality, origins, or by other means, and to treat everyone as a man. The ideal excludes also any individual egoism, nastiness, aggression, laziness and other vices. Petrażycki's great ideal of love assumes stronger sympathy and involvement in doing good. The love that Petrażycki means is activity for the good of all people, and even for the good of animals. ${ }^{2}$

Petrażycki means not only development of ethical and legal principles or acting according to them, but also he expects more radical and deep transformation of man. That needs to go on the level of our deepest emotions, so they would motivate us to noble actions only. Petrażycki means that proper mental dispositions should be formed: 'That is about gradual structuring a certain ideal composition of emotional mind, and gradual eradication of egoistic dispositions, and in that manner introduction of the mental ability to act correctly...development and strengthening charitable (karytatywny) emotional dispositions, and in that way creation of mental necessity that one's actions are good, gracious, merciful etc' [54, p. 159]. So realization of the great ideal of love is possible only in the way of knowing mental mechanisms, especially emotional ones, and in the way of shaping them properly. Once the ideal is realized the law and morals become useless: 'when the proper fully social education and the psyche of love in our broad sense are achieved...then the law loses whole its sense and its existence becomes even psychologically impossible' [54, p. 165]. Any state authority becomes needless too. The humanity becomes a mature community of people acting upon positive desires (impulsions). The realization of that is still very far. Lots of obstacles needs to be removed and many important reforms have to be implemented. Some of them will be described below.

\section{Petrażycki's Logical and Methodological Claims}

Petrażycki's interests and aspirations were very vast. He had a reformer's spirit and he let it act. He criticized principles of classical logic, offered a new classification of propositions/positions and a 
new classification of sciences. He elaborated a new methodology of science, and he attempted to reform science in general. The most fully he applied his ideas in the area of psychology, theory of law and sociology.

The most exhaustively he formulated his program of so called positional logic in New Principles of Logic and Classification of Skills (Nowe podstawy logiki i klasyfikacji umiejętności). His idea was to supplement the logics of 'propositions' (or logical sentences) with the science concerning so called positions as a homogenous theoretical category. According to him the foregoing logics was 'limp' (it took into account too narrow class of propositions), because it rejected propositions that had no 'objective-cognitive' nature. Nevertheless according to Petrażycki's view logics should deliver support and direction not only in the domain of seeking the truth, but also in the area of rational obtaining position toward things and of rational acting. Positions are simple senses or contents of sentences that are not possible to divide [54, p. 5]. Let us take the sentence 'A cold rock lies.' It contains at least three positions: 'a rock exists,' 'a rock lies,' 'a rock is cold.' And another sentence: 'Jupiter sleeps.' It contains at least three positions: 'Jupiter exists,' 'Jupiter lives' and 'Jupiter sleeps.' Petrażycki claims that merely the first one is independent and only examining its truthfulness makes possible to consider whole the sentence. The position 'Jupiter sleeps' assumes the position 'Jupiter lives.' Various respective predicates point to subsequent positions. Petrażycki divided positions into two basic groups: I. Objective-cognitive positions and II. Subjective-relative ones. The former are divided into 1) Class (theoretical) positions and 2) Non-class (particular-individual) ones: i. Descriptive (e.g. in geography), ii. Historical, and iii. Predictive. Subjective-relative positions are divided into: 1) Critical (they express personal, emotional attitude of the subject): i. Negatively valuating, ii. Positively valuating, or 2) Postulated (they express obligations, demands or requirements): i. Subjective (concerning actions), ii. Objective. Subjective ones may be a) Teleological and b) Principal (normative): positive (dogmatic) or non-positive (intuitive).

In his methodology Petrażycki postulated to introduce class concepts and the criterion of scientific propositions adequacy [cf. 43, see also 18, 34, 64, 66]. Let us start form the latter. The most generally, the principle of adequacy demands to 'refer what one claims to proper classes of objects that are sufficiently broad,' and not to narrow unduly the class of objects that the given sentence concerns. The sentence 'All men are mortal' is true but inadequate, for one can say that 'mortal' are not only men but living organisms at all. Theories that are scientifically adequate may not be false, but in the same time, not every truth is important from their point of view and not every truth needs to be taken on board. Adequate theories are properly general, referring to properly broad classes - not too narrow, and not too wide. In other words, adequate theories are accurate given their range concerned.

Theories that are narrow because of their range - that is 'limp' ones - are theories that 'break the principle of sufficiently broad class, i.e. theories whose predicates are being referred to too narrow ranges of objects' [43, p. 128]. There are also theories that are absolutely defective. They are false when referred to whole the class [43, pp. 128-150]. According to Petrażycki in science there are lots of theories that are false, limp or jumping, but also such (they usually are more compound) that they contain theses that are limp and jumping as well. He declared war against all theories of those kinds. ${ }^{3}$

It is also general class concepts that are important in scientific research practice. According to Petrażycki such concepts enable: 1) The general knowing phenomena of the reality, 2) Scientific theories constructing, 3) Understanding what those theories claim, and 4) systematization of knowledge [42, pp. 35-36]. Unfortunately, by his opinion, the contemporary science had not in its disposal either adequate concepts or adequate theories. Especially humanities and social sciences seek for their class, basic and central concepts: psychology seeks for the concept of mental phenomenon, the theory of law seeks for the concept of law, ethics and theory of morals seek for the concept of morality, sociology seeks for the concept of society, economy seeks for the concept of economy, the theory of state seeks for the concept of state and esthetics seeks for the concept of esthetic phenomenon. 
What are class concepts? A class is comprised of all objects (things, phenomena, processes etc.) that possess a given property characteristic for them or may be thought as possessing it. Petrażycki writes: 'The idea of all objects being white is a class concept, that is the concept of the class of white objects. The class comprises of all objects that possess that color or may be thought as possessing it' [43, p. 74].

It is not necessary to know all properties of an object to create a class concept, so it is not necessary to obtain complete and perfect knowledge of the object. What is enough is one of its properties and then one can divide the being analyzed group of objects into class of objects that possess the property and class of objects that do not. Furthermore it is important that class concepts are not limited to objects that exist in reality here and now, but contrarily, the latter comprise a small part of them merely. In addition to them, also all the objects that existed in the past, and those that will exist in future belong to the class. Moreover lots of concepts embrace objects that may be merely thought of, but they do not exist in nature [43, pp. 74-75]. The essential rules concerning class concepts and class creation Petrażycki put into the two of his theses:

1) To create a class concept means to formulate a thought according to the schema: objects possessing the property $a$.

2) Then one has to prove that any object possessing the property $a$ possesses also a further property $b$ or further properties $b, c, d$ etc. [43, p. 157].

Only class concepts that are understood in that manner are - according to Petrażycki - a good basis for scientific theories creation and scientific classifications construction. It is so for class concepts are merely links used when constructing a theory - an adequate theory. The ability to create adequate theories is the only proper way to test scientific value of a class concept .

\section{Detailed Analysis of Moral and Legal Phenomena}

Legal and moral phenomena are - according to Petrażycki - of mental kind, so the most accurate method to know them is, in his view, the introspection. Nevertheless it has to be underlined that method is basic but not the only one. Strictly speaking Petrażycki postulates to apply a mixed method that contains: usual and experimental introspection, and also observation of external behaviors that are symptoms of internal experiences. By introspection Petrażycki means internal observation of various mental phenomena: simple sensations, experiences and imaginations [43, pp. 58-62].

Petrażycki considers also the experimental form of introspection. In his opinion any observation - thus self-observation too - may by experimental. By experimental method of introspection Petrażycki means a controlled observations of one's experiences that is based on producing, modifying, stopping and optionally repeating them. In order to do those one does not need any specialized laboratories or devices.

An important addition to such research should be the analysis of accounts and descriptions concerning experiences of various kinds coming from other people. They are mainly historical accounts, chroniclers', journalists', biographers' and travelers' descriptions. Next to that Petrażycki postulates profound and broad observation of external symptoms.

Overall Petrażycki was in favor of research that would be the basis to establish many general statements concerning physiological phenomena (especially psychological, for they contain moral and legal emotions) in case of not only humans but also animals (though not of all species).

\subsection{Critique of Foregoing Classification of Mental Phenomena and Proposal of New Division}

By his own logical-methodological principles Petrażycki criticizes the foregoing classifications of mental phenomena and gives a new one, additionally he offers a scientific explanation of emotions. Coming from Kant the division of mental phenomena into cognition, the will and emotions was widely spread in the nineteenth century, though there were also such approaches where emotions 
were a form of will, and the will was a detailed case of cognition. Petrażycki found that mixing or relocating various emotional experiences in various categories as the vice of the very basis of the classification. Classes of cognition, feelings and the will are not clear. From one point of view - as Petrażycki argues - the scope of all mental phenomena (that includes cognition, feelings and the will) is too narrow for they do not exhaust whole the mental life. On the other hand ranges of all the three domains of contemporary psychology - psychology of cognition, emotions and the will - was too broad, and that was the reason why some extraneous elements were introduced to them, especially in case of feelings.

According to Petrażycki it was methodologically wrong to create various complexes ('eclectic groups') containing for example imaginations and pleasures or imaginations and irritations (e.g. the love as combination of imagination and pleasure, the hate as combination of imagination and irritation), and to describe such sets as feelings. In his opinion, according to the laws of logics and science, emotional elements and emotional-cognitive complexes should be strictly distinguished, and only experiences of pleasure and irritation should be found as feelings.

Petrażycki consequently offered his own classification of mental phenomena and scientific explanation of emotions. He divided all basic mental phenomena into two classes, the second one was divided into two subclasses further:

1) Two-sided, that is, passive-active ones, they include impulsions/emotions;

2) One-sided ones, they are divided into:

a) One-sided passive ones (cognitive and emotional experiences) and

b) One-sided active ones (experiences of the will).

For phenomena of the first class Petrażycki reserves two names 'emotions' and 'impulsions.' Etymologically he finds the first term the most suitable. It comes from Latin 'movere,' and that means 'move,' and from 'emovere,' and that means 'move strongly, shake' or - if you take into account that ' $e$ ' means 'from' - 'move outside from inside.' Below the formation and the nature of emotions, and also ethical emotions and norms formation will be discussed. Now let us consider one-sided phenomena shortly.

Feelings as passive experiences caused by external and/or internal stimuli, and feelings as experiences of pleasure or irritation are one-sided passive. They appear on the later stage of evolutionary development as the result of impulsions differentiation. The latter means 'weakening and declining the drive element on the one side, and isolating more differentiated experiences from primitive, misty and indefinite impulses on the other' (43, p. 403). One-sided passive phenomena sensations and feeling - are simple 'impulses', that is, experiences and perceptions without any move reaction.

The will as heading do change, governing and directing the action belongs to one-sided active phenomena (one can have the will to work despite being tired, or the will to seek for the solution continuously despite having no satisfying results). Such experiences are 'presented to one as active strivings of his ego, they are determined to make or create something in near or further future' [43, p. 256]. Nevertheless the will itself is neither an internal impulse to act nor an act itself. The will is a homogenous class of phenomena. It is an intermediate link between impulsions (or other motives) and actions (or ceasing some actions), and it is responsible for one's choices, resolutions and decisions. The will is formed 'not by various elements of mental life, but...by simple (noncomplex) experiences that are strictly active (striving). The latter comprise a separate kind of mental life elements (that is the most simple elements that are not possible to divide into more simple ones)' [43, p. 265].

\subsection{Explanation of Emotions}

Petrażycki assumes the biological perspective in explanations of impulsions: the evolutionary and physiological-neurological ones. In his opinion impulsions are evolutionary basis for the psyche development: 'From the historical and evolutionary point of view it seems very probable that the primary basis of the psyche development were emotions, whereas one-sided elements - active and 
passive as well - were further creations of the evolution and of the emotions differentiation' [43, $\mathrm{p}$. 403].

Impulsions are the basic form of mental phenomena. They are - as Petrażycki formulates that - the prototype of mental life: 'They are the counterpart of afferent-efferent anatomical structure of nervous system (of stimulatory-motoric function of that system), and because of that they are the prototype of any mental life that is two-sided: passive-active' [43, p. 403]. Secondarily one-sided experiences arise. Nevertheless that form of mental life never stops, but it always accompanies secondary passive feelings and the active will (that will be discussed below).

According to Petrażycki, everyday - from the morning to the evening - one experiences many thousands of various impulsions. Lots of them are mild and soft. Most of them are impossible to capture with the naked eye. They are hidden and unknown: 'emotions are hidden and unavailable for cognition' [43, p. 420]. Usually they go on unnoticed, but some of them are quite intensive. They all make one's muscles, body and mind move: 'Their function is to bring body moves and other activities (e.g. mental work and other so called internal activities) producing directly some physiological and psychic processes...or a given will (activity of the will)' [44, vol. 1, p. 8]. Emotions - though unconsciously - strongly influence one's thinking, decisions and activity.

Because of the direction of emotions' acting Petrażycki made the division into: 1) appulsive (attractive) and 2) repulsive emotions. The former are of the approval kind - they push and motivate one to some given behavior. Hunger-appetite, thirst, desire and curiosity belong here. The latter are the opposite - they are of the disapprobation and rejection kind. They include hate and disgust (and also fear and horror). Repulsions may appear in situations of exaggeration or excess, e.g. in case when one eats and his appetite is satisfied but the organism still incepts the food (and the same it is in case of thirst satisfaction). Then overeating appears and it is accompanied by the rejection reflex: 'in case of excess, stimuli of the contrary direction (repulsive ones) appear instead of instinctiveappetitive stimuli' [43, p. 356].

The aim of appulsive and repulsive stimuli is to support the organism in its life functions. Appulsive stimuli assist the organism in its development, whereas repulsive ones work to secure the living being from harmful factors.

In his Theory of State and Justice (Teoria państwa i prawa) Petrażycki distinguishes 1) special impulsions and 2) abstractive impulsions (formal ones). Special (simple, specific, and diverse) ones are genetically determined and they lead to strictly defined behavior [44, vol. 1, pp. 19-20, 22, 35]. Emotions of that kind adapt the organism to perform various tasks, for example hunger-appetite, curiosity, fear, shame. On the other hand abstractive impulsions are evoked by prescriptions, bans, requests or advices directed to one by various subjects. For example, rapidly spoken calls 'silence!' and 'don't touch!' bring to one's mind some given drive stimuli that push him to act according to the call. Character and direction of the action is additionally strengthened by some other mental elements, e.g. by imaginations: 'the energy of formal impulsions (legal ones included) needs an additional amplification by some other mental elements' [43, pp. 217-219]. The latter are an essential element of moral and legal experiences.

\subsection{Genesis of Ethical Emotions and Moral and Legal Norms}

Moral and legal experiences are two species of one kind of ethical phenomena.

A minimal content of an ethical experience is the action imagination, i.e. imagination of the action along with an appulsive or repulsive ethical emotion accompanying it. When an imagination of a deed (e.g. a murder, a lie, a betrayal, an act of mercy or loyalty) appears in one's consciousness, then the ethical emotion that is relevant to the given imagination begins to work.

The class of all ethical experiences (and also of moral and legal ones) is characterized by the two following properties. First, they always possess a specific mystic-authoritative feature, that is, they always are presented as something having a higher authority: 'That authoritative character has some consequences in language, poetry, mythology, religion and other similar creations of human spirit as relevant fantastic imaginations that encourage one to some given action, and that concern 
some mystic voice addressing one and speaking to him' [44, vol. 1, pp. 49-50]. The voice belongs mainly to some theological, metaphysical and moral beings like God and 'divine voice' that one must listen to, Socrates' daimonion, conscience and 'voice of conscience,' and also 'spirit of the nation,' 'the common will,' 'instinct of the species.' Those 'fantastic imaginations' arise as feature projections and subject creations. Second, they are kind of internal limitation: 'one experiences them as internal limitation of freedom, as a specific obstacle in the free choice, assessment and realization of one's inclinations, strivings and plans, and as a rigid pressure forcing one to act according to the imagination that is associated with relevant emotions' [44, vol. 1, p. 51]. The feeling of limitation comes out from that a) Principles of action that are derived from ethical impulsions (from the duty) are higher laws, calls and bans, but not requests, suggestions or advices that are aimed by somebody, and b) They push the subject into the specific state of emergency breaking those calls and bans leads to vexatious consequences.

Before we discuss the character of moral and legal emotions, let us say a few words about the idea of projection that accompanies any emotional phenomena (though Petrażycki considered projections acting within esthetic and ethical emotions mainly).

Simply speaking a projection is bestowing - under influence of various impulsions - some features upon objects and finding them real, whereas actually they exist merely intentionally in the world of mind. In Introduction (Wstęp) Petrażycki noted that impulsions 'make that people experiencing those processes deem that external objects really possess some features that they actually do not, or even that as the effect of some external processes people get under the illusion that in the external world there are some objects that actually do not exist' [43, p. 48]. In Theory of Law (Teoria prawa) he explains the point by relevant examples. He assumes two kinds of projections. Projections of the first kind bestow some features upon actually existing objects. An object being perceived evokes in one some given impulsions - appulsions or repulsions - that bestow on those perceptions some entirely new complexions. Since then the given object is seen by the person in a different way, a new form. For example a freshly made roast may delight by its look and awake the appetite with the smell. Under influence of such drive stimuli the roast looks much more tasteful. One ascribes to it specific features, and he says that it is tasty, appetizing, delicious, exquisite. On the other hand if one perceives a chunk of raw and bad meat (that is going to be roasted), its look evokes repulsion or aversion, and that will make one to say that it is terrible, awful, ugly, filthy. In sum, in case of appulsions the bestowed features would be positive, and in case of repulsions they would be negative.

Projections of the second kind rely on bestowing features (apparent ones) and construing various not existing objects: 'Impulsive fantasy calls up to life not only various features of objects and phenomena...but also creatures of other categories that do not exist in reality' [44, vol. 1, p. 56]. Petrażycki calls that kind of projections 'emotional fantasy' or 'impulsive fantasy,' and what one imagines as objectively existing he calls 'emotional phantasms' or 'projective creatures,' and also 'ideological creatures.' Norms, calls and bans of a higher authority belong here. 'Namely - he writes - such creatures of emotional projection (or emotional phantasms) include those categorical imperatives of a higher authority that in ethical experiences occur as objectively existing and directed to particular subjects, and also those peculiar states of attachment, obligation, dependence and freedom limitation that one ascribes to subjects of his imagination such that those being imagined ethical laws dictate them the appropriate conduct or ban it' [44, vol. 1, p. 59]. Such projection is naive and indiscriminate, and Petrażycki rejects it. Instead he offers an unsatisfactory compromise. He postulates the following convention: still we are going to talk about projections and phantasms but have something different in mind. His idea is that one should 'talk about duties, their content, kinds of them etc. as if they really existed but keeping in mind that actually he talks about emotional phantasms, and that their real counterparts are known emotional and intellectual processes' [44, vol. 1, p. 62]. Additionally he offers a small terminological change, namely the term 'ethical norm' should be replaced with the name 'imperative norm.' Imperative norms are projections such that their source is imperative impulsions. As projections they do not determine 
any definite directions, and that is why they may evoke very different actions $[44$, vol. 1 , pp. $62-$ 63].

In Petrażycki's theory there are two kinds of emotional-intellectual ethical associations and their projections, two kinds of duties and norms: one-sided moral duties and two-sided legal duties. Morals rely on merely one-sided experiences of the duty. The one-sidedness of morals means that a subject experiences duties, calls and bans ('thou shalt not kill,' 'thou shalt not commit adultery,' 'thou shalt not steal'). Morals are 'free,' and that means that they lack any element of a claim that would give any authority to anyone. Naturally it is possible that some other people have some expectations, e.g. someone may expect that one helps him or gives him a handout, but that is entirely voluntary. Notice that someone's claim 'absolutely you must give me a handout' would sound strange and unjustified to anyone. Accordingly moral norms are imperative. Instead in the domain of law there are two-sided experiences: the duty on the one side, and the claim on the other. If one has a duty toward a subject then the subject has a claim toward the one. The employer has the duty to pay salary to his employee, and the employee may demand the payment for his work. Accordingly legal norms are imperative-attributive [43, 44, 52, see also 7, 22, 26, 32, 33, 61, 65].

According to Petrażycki it is essential that one's rights are somebody else's obligations, and one's obligations are somebody else's rights. As evidence of those he gives numerous linguistic analyses: 'besides or instead of expressions that are counterparts of such terms like 'right,' 'legitimation,' 'legal claim' everyday language uses expressions that mean someone's having an obligation or a debt, and those expressions are treated as synonymous' [44, vol. 1, pp. 74-75]. It is so in Slavic languages. For example in Russian the word 'liability' functions as 'debt', as in such phrases like: 'A liability is any property that is a debt of another person,' 'And the complainant together with the commissioner will come and he will reclaim his debt by force...' [44, vol. 1, pp. 74-75]. In the past, Polish word ' $d t u g$ ' (debt) meant not only - as it is today - an obligation, and that is what one is to give to somebody else back, but also what somebody may purport, pretend or claim the right to. For the word 'debtor' in old Polish there was the word 'iściec.' There is no doubt among researchers that the term meant an owner, a creditor and in other cases a debtor. It is similar in German, and also in Latin in Arabic, and in Semitic and Asian languages.

\section{Some Remarks on Two-Sidedness of Legal Norms}

When Maria Ossowska presented various ways in which researchers strived to distinguish legal and moral norms, she also mentioned distinction offered by Petrażycki, and she discussed some misunderstandings that one can meet when the distinction is concerned. Her remarks do not sound like entirely accurate. It seems that Ossowska defends Petrażycki's distinction at the price of sharpness and radicalness of his claims. Her first remark is doubtful, when she suggests that Petrażycki 'did not treat his distinction as describing state of fact,' but he construed it 'as a proposal, a project of a conceptual convention that would be useful in explaining some controversies' [38, p. 298]. On the other hand it seems that is one of the most important distinctions Petrażycki offered in his construction of theoretical knowledge. As one can read above, the theory of ethical phenomena ('ethology') is divided in his construction into two theories: the theory of law and the theory of morals. Without that one cannot understand Petrażycki's policy of the law.

According to Ossowska, the second Petrażycki's mistake is that he 'makes the distinction rigid and absolute, whereas in his intentions that was to be rather fluxional. One and the same norm, for example the norm that forbids to lie or to cheat, one can treat as a legal or as a moral one, depending on what emotion accompanies it in the given while' [38, p. 299]. However there is lots of evidence that she is wrong. Petrażycki's distinction into legal and moral norms means that moral norms are merely imperative, and the legal norms are merely imperative-attributive. As Józef Nowacki notes: 'In the light of characteristic of moral and legal emotions and norms the relation between the law and morals in Petrażycki's theory would be separation' [33, p. 53]. For no imperative experience may be imperative-attributive, and no imperative-attributive experience may be imperative, any norm may be merely imperative or imperative-attributive: an imperative norm is 
moral, and an imperative-attributive one is legal. Petrażycki himself points out that legal and moral phenomena are separate, especially when he underlines that distinction was offered for the sake of the character of subjective experiences, for they may be merely imperative or merely imperativeattributive [44, vol. 1, footnote 34, p. 74]. There are still some problems concerning the distinction. Nowacki (mentioned supra) pointed some of them.

Petrażycki points out that morals does not contain claims. However Nowacki refers to utterances in which a demand or a claim in the domain of morals is mentioned. In such situations norms that Petrażycki calls moral are imperative-attributive and become legal. Nevertheless it does not need to be this way. The demand in moral and legal norms may be entirely different in the object and character, and Petrażycki suggests it himself. A demand in the domain of morals is 'objectless' - nothing is due to the one who is demanding [33, pp. 54-56]. Nowacki points out to another difficulty yet. Imaginations of various kinds of conduct (jealousy, lie, cheating) evoke certain emotions that are moral or legal, and further they effect respective norms. Petrażycki does not exclude that sometimes simultaneously moral and legal emotions, that is, imperative and imperative-attributive experiences appear. On that level one would not be able to distinguish them. The relation between them would not be separation, where one experience exclude another. Then the subject would be in a paradoxical position for he would experience his claims (the condition of legal emotions) and he would not experience them (the condition of moral emotions). Strictly speaking, the problem is that imagination of a deed may evoke legal as well as moral emotions. That is kind of the problem of individuation: you do not know what makes that emotions of one or another kind appear.

The problem of relation between morals and the law has been widely discussed in the past and it is still unsolved. That relation is found in a different way by defenders of the natural law theory and supporters of legal positivism. Controversy between Herbert L. A. Hart (11) and Ronald Dworkin (8) is an inspiration for many. Some compromises are possible too. A third way representative is Arthur Kaufmann. He proposes hermeneutic philosophy of the law [13], [14]. Basically researchers agree that morals influence the genesis of the law and infiltrate legal systems deeply; on the other hand the law impacts morals (for example human rights do). Today relation between morals and the law is being analyzed on many levels and in many contexts. For example Wiesław Lang notices: 'Connection between the law and morals appears on three levels of the legal order, namely, on level of making the law, level of applying the law, and on level of interpreting the law and the doctrine of law' [22, p. 163]. Upon every of those levels one should consider some next problems and distinctions. ${ }^{4}$

In Petrażycki's system the law and morals have the motivational and educational role. According to him the legal motivation is much more important in social life than the moral one. The latter implants the feeling of duty merely and by that to a degree it shapes a slavish soul. Petrażycki uses the metaphor of water and wine here. The legal motivation he compared to water, that is, to something one cannot live on a day without. On the other hand he equated morals with wine, that is to a drink one makes use of from time to time. The social progress - that Petrażycki cared about so much - relied on formation of a given character of the psyche: on implanting in the social psyche imaginations of good conduct and associations of that with emotions.

It is hard to refer here to all problems concerning norms in the theory of law that Petrażycki discusses, nevertheless one is worthy of note. Petrażycki was interested in the social aspect of law. Emotions and experiences of moral and legal kind are subjective, whereas activity of a man, morals and the law are largely objective. One may raise the question if it is possible to find a bridge between subjectivity of emotions and objectivity of the law. Petrażycki strived to solve the problem by introducing the idea of emotional infecting that every day one has a brush with in social relations, behaviors, external expressions and speech. By language one communicates not only imaginations and expectations but also various assessments and emotional experiences [54, p. 446]. The infecting means that emotions come from person A to person B. When one accompanies happy people he becomes happy himself. When one contacts sad persons he turns sad. That is the same 
with all emotions, moral and legal ones as well. Petrażycki claims that the infecting is one of important means of perfecting social life and progress.

The infecting is also important in reference to the objectives Petrażycki sets for his politics of law. As it is said at the beginning above, he assumes that in some future morals and especially the law will decline and vanish. The law would be merely a temporary construction that would serve to educate a man, and he would experience positive emotions only and would infect others with them. One can doubt if that would be possible and enough for the humanity would live in harmony.

\section{References}

1. Babb, H. W. Petrazhitsky: Science of Legal Policy and Theory of Law, Boston University Law Review 17/18, 1937, pp. 793-829.

2. Babb, H. W. Petrazhitsky: Theory of Law, Boston University Law Review 18, 1938, pp. 511-578.

3. Barwicka-Tylek, I. W kwestii 'psychologiczności' psychologicznej teorii prawa Leona Petrażyckiego, Państwo i Prawo 2 (768), 2010, pp. 44-56.

4. Barwicka-Tylek, I. Leon Petrażycki, In K. Chojnicka and M. Jaskólski (eds.), Stownik historii doktryn politycznych, vol. 4, Warszawa: Wydawnictwo Sejmowe, 2009, pp. 567-578.

5. Biernat, A. Poglady filozoficzne Leona Petrażyckiego i ich interpretacje, Toruń: Wydawnictwo Adam Marszałek, 2001.

6. Brożek, B. Emocje jako fundament prawa. Uwagi o teorii Leona Petrażyckiego, In. J. Stelmach,

J. Brożek, Ł. Kurek, K. Eliasz (eds.), Naturalizm prawniczy. Stanowiska, Warszawa: Wolters Kluwer, 2015.

7. Denzin, N. K. Interaction, Law and Morality: The Contribution of Leon Petrażycki, In J. Górecki (ed.), Sociology and Jurisprudence of Leon Petrażycki, Urbana, Chicago, and London: University of Illinois Press, 1975, pp. 83-105.

8. Dworkin, R. Taking Rights Seriously, Massachusetts: Harvard University Press, 1977.

9. Giaro, T. La Civilpolitik di Petrażzycki, Index 23, 1995, pp. 97-157.

10. Górecki, J. (ed.). Sociology and Jurisprudence of Leon Petrażycki, Urbana, Chicago, and London: University of Illinois Press, 1975.

11. Hart, H. L. A. The Concept of Law, Oxford: Oxford University Press, 1961.

12. Hazard, J. N. Communists and Their Law: A Search for the Common Core of the Legal Systems of the Marxian Socialist States, Chicago and London: University of Chicago Press, 1969.

13. Kaufmann, A. Rechtsphilosophie im Wandel. Stationen eines Weges, Frankfurt am Main: C. H. Beck, 1972.

14. Kaufmann, A. Moral, In Staatslexikon: Recht - Wirtschaft - Gesellschaft, Freiburg Basel Wien: Herder (Görres-Gesellschaft), 1987, pp. 1219-1227.

15. Kojder, A. Gorzkie lata Leona Petrażyckiego w Uniwersytecie Warszawskim, Studia Iuridica 17, 1990, pp. 175-189.

16. Kojder, A. The Sociology of Law in Poland: Past and Present, In V. Ferrari (ed.), Sociology of Law: A Worldwide Documentary Enquiry, Milan: Giuffre Editore, 1990, pp. 632-659.

17. Kojder, A. Godność i siła prawa, Warszawa: Oficyna Naukowa, 2001.

18. Kotarbiński, T. Pojęcie teorii adekwatnej, Studia Filozoficzne 4, 1973, pp. 3-16.

19. Kowalski, J. Psychologiczna teoria prawa i państwa Leona Petrażyckiego, Warszawa: PWN, 1963.

20. Lande, J. Socjologia Petrażyckiego, Przegląd Socjologiczny 12, 1958, pp. 229-265.

21. Lande, J. Studia z filozofii prawa, Warszawa: PWN, 1959.

22. Lang, W. Aksjologia prawa, In B. Czech (ed.), Filozofia prawa a tworzenie i stosowanie prawa, 
Katowice: Instytut Wymiaru Sprawiedliwości - Ośrodek Terenowy przy Sądzie Wojewódzkim w Katowicach, Katowice, pp. 120-132.

23. Langrod, G. S. L'Oeuvre juridique et philosophique de Leon Petrazycki, Brussels, 1957.

24. Langrod, G. S., and M. Vaughan. The Polish Psychological Theory of Law, In W. J. Wagner (ed.), Polish Law Throughout the Ages, Stanford: Hoover Institution Press, 1970, pp. 299-362.

25. Laserson, M. M. The Work of Leon Petrazhitsky, Columbia Law Review 51 (1), 1951, pp. 4163.

26. Lazari-Pawłowska, I. Leon Petrażycki - teoretyk moralności i moralista, Etyka 9, 1971, pp. 4163.

27. Lewin, K. Principles of Topological Psychology, New York and London: McGraw-Hill, 1936.

28. Licki, J. Motywacyjne i wychowawcze działanie prawa jako podstawa naukowej polityki prawa, In J. Kurczewski (ed.), Prawo i Społeczeństwo, Warszawa: PWN, 1975, pp. 233-270.

29. Meyendorf, A. The Theory of Petrazhitsky, In W. I. Jennins (ed.), Modern Theories of Law, London: Oxford University Press, 1933, pp. 21-37.

30. Morawski, L. Wstęp do prawoznawstwa, Toruń: Towarzystwo Naukowe Organizacji i Kierownictwa. Stowarzyszenie Wyższej Użyteczności „Dom Organizatora”, 2004.

31. Motyka, K. Wpływ Leona Petrażyckiego na polska teorię i socjologię prawa, Lublin: Redakcja Wydawnictw KUL, 1993.

32. Motyka, K. Amerykańskie Petrażycjana: Law and Morality w oczach krytyki, In Prawo $i$ ład spoteczny: ksiega jubileuszowa dedykowana Profesor Annie Turskiej, Warszawa: Uniwersytet Warszawski, 2000, pp. 314-328.

33. Nowacki, J. O rozróżnieniu prawa i moralności w teorii Leona Petrażyckiego, Studia Filozoficzne 5, 1981, pp. 51-62.

34. Opałek, K. Problemy metodologiczne nauki prawa, Warszawa: PWN, 1962.

35. Opałek, K. Zagadnienia teorii prawa i teorii polityki, Warszawa: PWN, 1986.

36. Opałek, K., and J. Wróblewski. Zagadnienia teorii prawa, Warszawa: PWN, 1969.

37. Opałek, K. (ed.). Z zagadnień teorii prawa i teorii nauki Leona Petrażyckiego, Warszawa: PWN, 1969.

38. Ossowska, M. Podstawy nauki o moralności, Warszawa: PWN, 1966.

39. Petrażycki, L. Die Fruchtverteilung beim Wechsel der Nutzungsberichtigen, Berlin, 1892.

40. Petrażycki, L. Die Lehre vom Einkommen, vol. 1-2, Berlin, 1893-1895.

41. Petrażycki, L. Bona fides v graždanskom prave, St Petersburg: Tipografiya M. M. Stasyulevica, 1897.

42. Petrażycki, L. O motivach čelovečeskich postupkov v osobiennosti o etičeskich motivach $i$ ich raznovidnostijach, Petersburg, 1904; id. Über die Motive des Handelns und über das Wesen der Moral und des Rechts, Berlin, 1907; id. O pobudkach postępowania i o istocie moralności i prawa, trans. by J. Licki, Warszawa, 1924, 2002.

43. Petrażycki, L. Vvedenie v izučenie prava i nravstvennosti, Petersburg 1905; id. Wstęp do nauki prawa i moralności. Podstawy psychologii emocjonalnej, trans. by J. Lande, Warszawa: PWN, 1959.

44. Petrażycki, L. Teorija prava i gosudarstva v svjazi s teorijej nravstvennosti, vol. 1-2, Petersburg 1907; id. Teoria prawa i państwa w zwiazku z teoria moralności, trans. by J. Lande, vol. 1-2, Warszawa: PWN, 1959-1960.

45. Petrażycki, L. K voprosu o social'nom ideale i o vozroždenii estestvennogo prava, Juridiczeskij Wiestnik 1913; id. O ideale społecznym i odrodzeniu prawa naturalnego, J. Finkelkraut (Licki) (ed.), Warszawa, 1925. 
46. Petrażycki, L. O różnych gatunkach przewidywań i o znaczeniu praktycznym teoryj, Prace Socjologiczne 1, 1935, pp. 1-6, reprint: Prakseologia 1, 1974, pp. 7-17.

47. Petrażycki, L. O dopetniajacych prądach kulturalnych i prawach rozwoju handlu, J. Finkelkraut (Licki) (ed.), Warszawa, 1936.

48. Petrażycki, L. Nauka o kategoriach, J. Finkelkraut (Licki) (ed.), Warszawa, 1939

49. Petrażycki, L. Nowe podstawy logiki i klasyfikacja umiejętności, J. Finkelkraut (Licki) (ed.), Warszawa, 1939.

50. Petrażycki, L. O filozofii, J. Finkelkraut (Licki) (ed.), Warszawa, 1939.

51. Petrażycki, L. Szkice filozoficzne, vol. 1, O tak zwanej metodzie krytycznej oraz o metafizyce i filozofii praktycznej Kanta, J. Finkelkraut (Licki) (ed.), Warszawa, 1939.

52. Petrażycki, L. Law and Morality, trans. by H. W. Babb, Cambridge, MA: Harvard University Press, 1955.

53. Petrażycki, L. Wstęp do nauki polityki prawa, Warszawa: PWN, 1968.

54. Petrażycki, L. O nauce, prawie i moralności. Pisma wybrane, J. Licki, and A. Kojder (eds.), Warszawa: PWN, 1985.

55. Pietrzykowski, T. Intuicja prawnicza. W strone zewnętrznej integracji teorii prawa, Warszawa: Difin, 2012.

56. Pietrzykowski, T. Naturalizm i granice nauk prawnych. Esej z metodologii prawoznawstwa, Warszawa: Wolters Kluwer, 2017.

57. Podgórecki, A. Założenia polityki prawa, Warszawa: Wydawnictwo Prawnicze, 1957.

58. Podgórecki, A. Unrecognised Father of Sociology of Law: Leon Petrażycki, Law and Society Review 15 (1), 1981, pp. 183-202.

59. Probucka, D. Psychologizm w etyce Leona Petrażyckiego, In A. Olech (ed.), Psychologizm antypsychologizm, Kraków: Aureus 2001, pp. 191-197.

60. Sadurska, R. Jurisprudence of Leon Petrażycki, American Journal of Jurisprudence 32, 1987 , pp. 63-98.

61. Sorokin, P. A. Review: Leon Petrażycki, Law and Morality, Harvard Law Review 69, 1956, pp. 1150-1157.

62. Szacki, J. Wstęp: krótka historia socjologii polskiej, In J. Szacki (ed.), Sto lat socjologii polskiej: od Supińskiego do Szczepańskiego. Wybór tekstów, Warszawa: PWN, 1955, pp. 11-119.

63. Timasheff, N. S. Petrazhitsky's Philosophy of Law, In P. L. Sayre (ed.), Interpretations of Modern Legal Philosophies: Essays in Honor of Roscoe Pound, New York: Oxford University Press, 1947, pp. 736-789.

64. Woleński, J. Metodologiczne dążenia Petrażyckiego a współczesna teoria nauki, In K. Opałek (ed.), Z zagadnień teorii prawa i teorii nauki Leona Petrażyckiego, Warszawa: PWN, 1969.

65. Ziembiński, Z. Normy moralne a normy prawne. Zarys problematyki, Poznań: UAM, 1963.

66. Ziembiński, Z. Metodologiczne zagadnienia prawoznawstwa, Warszawa: PWN, 1974.

67. Ziembiński, Z. Problemy podstawowe prawoznawstwa, Warszawa: PWN, 1980.

68. Znamierowski, Cz. Psychologiczna teoria prawa. Analiza krytyczna, Przeglad Filozoficzny 25, 1922, pp. 1-78.

69. Zyzik, R. Ideał społeczny w polityce prawa. Perspektywa ewolucyjna, Archiwum Historii Filozofii i Myśli Społecznej 60, 2015, pp.175-188.

70. Zyzik, R. Czy Leon Petrażycki był prekursorem behawioralnej ekonomicznej analizy prawa? Forum Prawnicze 39, 2017, pp. 21-33. 


\section{Notes}

1. Though Petrażycki's theory of law is found as his original achievement, but it was not entirely innovative. At least some experts say so. For example Jerzy Lande thought Petrażycki as continuator of psychological tradition in law and ethics. In his opinion Petrażycki followed such jurists as Friedrich Carl von Savigny, Ernst Rudolf Bierling and Léon Duguit [21, pp. 320-321].

2. The ideal of love formulated in that manner - or in a very similar one - is not entirely new. Petrażycki himself comes back to stoic ethical ideal. He mentions teaching by Buddha, Jesus or Paul the Apostle. For Petrażycki's politics of law, its aim, detailed tasks and educational function see also Andrzej Kojder's analysis [17, pp. 155-172].

3. It is obvious that one should avoid false theories. However it seems that Petrażycki does not count that scientists sometimes deal with isolated and very detailed problems. One can offer a general theory of action, and a narrower theory of motivation, and within that a theory of biological motivation, and then a theory of drives or a theory of emotions, but also a theory of physiological changes in emotional processes, theory of emotional expressions etc. Finally some theories may be jumping, and other may be limp, but both would be necessary and useful.

4. Lech Morawski (among others) points out to three possible kinds of relations between the law and morals. Those relations are material, validational and functional. The latter concern the influence of morals upon the law and vice versa. Material relations refer to content of legal and moral norms. Some behaviors are regulated only by the law, and some others only by morals, but also there are lots of legal and moral norms that have the same content (e.g. 'thou shalt not kill'). Validational relations refer to the basis of legal and moral norms standing. For example, according to classic natural law theories moral norms should be the basis for legal norms. Other theories (e.g. legal positivism) defend the independence and separation of legal and moral norms [30]. 